\title{
Diagnosis and treatment difficulties in 18-year-old male patient with hereditary hemochromatosis, chronic hepatitis B, Gilbert syndrome and ulcerative colitis
}

\author{
Katarzyna Sikorska1凶, Anna Liberek², Tomasz Romanowski³, \\ Agnieszka Szlagatys-Sidorkiewicz², Piotr Landowski² and Krzysztof P. Bielawski
}

1Departament of Infectious Diseases, and 2Department of Pediatrics, Gastroenterology, Hepatology and Nutrition, Medical University of Gdansk, Gdańsk, Poland; ${ }^{3}$ Molecular Diagnostics Division, Department of Biotechnology, Intercollegiate Faculty of Biotechnology of the University of

Gdansk and Medical University of Gdansk, Gdańsk, Poland

\begin{abstract}
Among possible causes of chronic hepatitis in adolescents most common are infections, autoimmune disorders and metabolic diseases. Thus, diagnostic procedures should be multidirectional. This study reports diagnosis and treatment difficulties in an 18-year-old male patient with hereditary hemochromatosis $(\mathrm{HH})$, ulcerative colitis (UC), chronic hepatitis B (CHB) and Gilbert syndrome. The presented case illustrates problems in diagnostics related to the presence of numerous disease conditions in one patient. It should be taken into consideration that these diseases coexisting in one patient can mutually affect their symptoms creating specific diagnostic difficulties.
\end{abstract}

Keywords: hereditary hemochromatosis, ulcerative colitis, chronic hepatitis B, Glibert syndrome

Received: 03 March, 2011; revised: 26 May, 2011; accepted: 01 June, 2011; available on-line: 02 June, 2011

\section{INTRODUCTION}

Among possible causes of chronic hepatitis in adolescents most common are infections, autoimmune disorders and metabolic diseases. Thus, diagnostic procedures should be multidirectional.

This study reports diagnosis and treatment difficulties in an 18-year-old male patient with hereditary hemochromatosis $(\mathrm{HH})$, ulcerative colitis (UC), chronic hepatitis B $(\mathrm{CHB})$ and Gilbert syndrome.

\section{CASE REPORT}

An 18-year-old male was admitted to the Department of Infectious Diseases with the diagnosis of chronic hepatitis B. His past medical history included ulcerative colitis that was diagnosed and treated at the age of 16 years in the Department of Pediatric Gastroenterology, Hepatology and Nutrition. He was admitted to this hospital due to repeated episodes of diarrhea with rectal bleeding. The diagnosis was established after colonoscopy and histopathological examination of specimens from the colon. In spite of recurrent rectal bleeding, the patient did not present anemia or iron deficiency (laboratory parameters are presented in Table 1).

Additionally, the patient was $\mathrm{HBsAg}$ positive, $\mathrm{HBeAg}$ negative, hepatitis $\mathrm{B}$ virus (HBV) infection had been observed since he was 7 years old. Most probably he was infected during infancy. At the age of 7 years liver biopsy was performed and minimal hepatitis was diagnosed. Serum ALT and AST activities were in the normal range. No treatment was administered. There was a family history of asymptomatic HBV infection in his father and mild unconjugated hyperbilirubinemia in his younger brother.

At the beginning his ulcerative colitis treatment consisted of mesalamine (5-aminosalicylic acid, 5-ASA) and corticosteroids rectally, but no remission was achieved. At the age of 17 years, azathioprine was added and initially good tolerance of this therapy with normalization of stools was observed.

After 5 months of this treatment the patient was admitted to the hospital due to weakness, jaundice, abdominal pain, vomiting and weight loss of $7 \mathrm{~kg}$. On physical examination, he presented hepatomegaly with tenderness in the right epigastrium. Laboratory investigations revealed neutropenia, rise of aminotransferase activities (ALT $421 \mathrm{IU} / 1$, AST $388 \mathrm{IU} / \mathrm{l}$ ) and elevated serum total bilirubin with its conjugated fractions (total bilirubin $8.56 \mathrm{mg} / \mathrm{dl}$, conjugated bilirubin $2.95 \mathrm{mg} / \mathrm{dl}$ ). Initially azathioprine-induced toxicity or exacerbation of chronic hepatitis B were suspected. The presence of HBV DNA in blood was confirmed but it did not exceed $100000 \mathrm{IU} / \mathrm{ml}$. Serum activity of thiopurine methyltransferase was within normal range $-9.36 \mathrm{nmol} / \mathrm{ml}$ per $\mathrm{h}$. No abnormalities were found in abdominal US imaging. Additional laboratory tests excluded hepatitis C infection, autoimmune hepatitis and Wilson's disease (laboratory parameters are presented in Table 1).

In the liver biopsy features of portal, periportal and intralobular chronic hepatitis were found. Moderate iron deposits were present in hepatocytes. Biochemical serum iron indices were also moderately elevated. Diagnosis of hereditary hemochromatosis was established after confirmation of the C282Y/C282Y muta-

\section{e-mail: ksikorska@gumed.edu.pl}

Abbreviations: AlH, autoimmune hepatitis; ALT, alanine aminotransferase; AST, aspartate aminotransferase; 5-ASA, 5-aminosalicylic acid; CHB, chronic hepatitis B; EASL, European Association For the Study of the Liver; HBeAg, hepatitis B e-antigen; HBsAg, hepatitis $B$ surface antigen; HBV, hepatitis $B$ virus; $\mathrm{HH}$, hereditary hemochromatosis; HLA, human leukocyte antigen; IBD, inflammatory bowel disease; RFLP, restriction fragment length polymorphism; $\mathrm{PCR}$, polymerase chain reaction; PSC, primary sclerosing cholangitis; UC, ulcerative colitis 
Table 1. Laboratory parameters at admission of a patient to the Department of Infectious Diseases

\begin{tabular}{|c|c|c|}
\hline Laboratory parameters & Result & $\begin{array}{l}\text { Normal } \\
\text { range }\end{array}$ \\
\hline Hemoglobin (g/l) & 13.9 & $14.0-18.0$ \\
\hline Hematocrit (\%) & 39.8 & $38.0-54.0$ \\
\hline $\mathrm{RBC}(\mathrm{T} / \mathrm{l})$ & 3.7 & $4.0-6.0$ \\
\hline WBC (G/)I & 2.76 & $4.00-10.00$ \\
\hline Neutrocytes (G/l) & 3.86 & $1.90-8.00$ \\
\hline $\operatorname{PLT}(\mathrm{G} / \mathrm{l})$ & 297 & $130-440$ \\
\hline ALT (U/I) & 421 & $5-41$ \\
\hline AST (U/I) & 388 & $5-37$ \\
\hline GGTP (U/I) & 92 & $8-61$ \\
\hline ALP (U/I) & 121 & $<390$ \\
\hline Total bilirubin (mg/dl) & 8.56 & $<1.2$ \\
\hline Conjugated bilirubin (mg/dl) & 2.95 & $<0.30$ \\
\hline $\lg G(g / l)$ & 12.09 & $5.36-15.47$ \\
\hline ANA & Negative & $1:<10$ \\
\hline SMA & Negative & $1:<10$ \\
\hline LKM & Negative & $1:<10$ \\
\hline pANCA & Negative & $1:<10$ \\
\hline Ceruloplasmin (g/l) & 0.457 & $0.15-0.30$ \\
\hline Copper in $24-$ hour urine $(\mu \mathrm{g} / 24 \mathrm{~h})$ & 37 & $<60$ \\
\hline Total protein $(\mathrm{g} / \mathrm{l})$ & 7.21 & $64-83$ \\
\hline Albumin (g/l) & 5.83 & $3.0-5.0$ \\
\hline Alfa1globulin (\%) & 6.5 & $2.9-4.9$ \\
\hline Alfa2globulin (\%) & 6.0 & $7.1-11.8$ \\
\hline Betaglobulin (\%) & 12.6 & $7.9-13.7$ \\
\hline Gammaglobulin (\%) & 16.6 & $11.1-18.8$ \\
\hline Iron ( $\mu \mathrm{g} / \mathrm{dl})$ & 211 & $60-170$ \\
\hline Transferrin sat. (\%) & 66 & $15-50$ \\
\hline Ferritin (ng/ml) & 492 & $18-250$ \\
\hline $\mathrm{HBsAg}$ & Positive & Negative \\
\hline $\mathrm{HBeAg}$ & Negative & Negative \\
\hline Anti-HBe & Positive & Negative \\
\hline HBV DNA in blood (IU/ml) & 75000 & Negative \\
\hline Anti-HCV & Negative & Negative \\
\hline HCV RNA & Negative & Negative \\
\hline
\end{tabular}

tion of the HFE gene. This genotyping was performed by PCR and restriction fragment length polymorphism (PCR-RFLP) analysis (Fig. 1) as described previously (Sikorska et al., 2008). Due to permanent unconjugated hyperbilirubinemia, Gilbert syndrome was suspected. UGT1A1 gene polymorphism was assayed by melting curve analysis of PCR-amplified genome fragments containing the site of mutation with fluorescent molecular probes (Fig. 2) as described elsewhere (Romanowski et al., 2009). Both homozygotic mutations UGT1A1*60 and UGT1A1*28, which are responsible for impairment of bilirubin glucuronisation and often co-occur, were detected.
DISCUSSION

The symptoms of chronic hepatitis warrant diagnostics directed to infectious, autoimmune and metabolic diseases. Hepatobiliary diseases are rather common in patients with inflammatory bowel diseases (IBD). The most frequent are primary sclerosing cholangitis (PSC) and autoimmune hepatitis (AIH) (Knight \& Murray, 2009). In the presented case, these diagnoses were excluded based on immunological analysis and liver biopsy. Diagnosis of $\mathrm{HH}$ type 1 was established eleven years after $\mathrm{CHB}$ and two years after UC diagnosis.

$\mathrm{HH}$ type 1 associated with HFE gene mutations is not considered a disease of the childhood or adolescence. Biochemical abnormalities of iron metabolism precede symptoms of tissue iron overloading that may finally lead to irreversible multiorgan damage. Although HFE gene mutations are detected with relatively high frequency in Caucasians $(1: 200-1: 400)$, clinical penetration of $\mathrm{HH}$ type 1 is much lower (Bomford, 2002). Recently, results of a prospective 12-year study demonstrated that only $28.4 \%$ of male and $1.2 \%$ of female C282Y/C282Y homozygotes presented clinical symptoms of iron-overload-related disease (Allen et al., 2008). The reasons for the low penetration of $\mathrm{HH}$ type 1 genotype include dietary habits, alcohol intake, toxicity of drugs, coexistence of chronic hepatitis $C$, but it seems that these factors do not explain the observed differences in expression of the disease in all C282Y/C82Y homozygotes (Beutler, 2003). Hepcidin, a central peptide regulator of iron homeostasis, is considered to play an important role in the development of hereditary hemochromatosis phenotype. Iron stores and inflammation are known inducers of hepcidin that acts as a negative regulator of iron absorption in the small intestine and iron release from macrophages (Nicolas et al., 2001; Pigeon et al., 2001; Nemeth et al., 2003). Impairment of hepcidin expression and disruption of hepcidin regulation has been demonstrated in HFErelated hemochromatosis (Bridle et al., 2003; Kulaksiz et al., 2004). Measurement of hepcidin expression was not possible in our case and we cannot show that the chronic inflammatory state related to UC influenced hepcidin expression and decreased iron absorption. Moreover, the role of hepcidin, a beta-defensin-like peptide, in the analysed case seems to be much more complex. Defensin deficiency is implicated in the pathogenesis of inflammatory bowel diseases. It might be suggested that decreased expression of hepcidin related to HFE gene mutation could influence development of UC symptoms (Verga Falzacappa \& Muckenthaler, 2005; Arnold et al., 2009; Ramasundara et al., 2009).

In the presented case, symptoms of $\mathrm{HH}$ were unexpected. Both biochemical and tissue marks of iron overload were diagnosed at the age of 18 during long-lasting exacerbation of ulcerative colitis, e.g., chronic inflammatory disease with recurrent rectal bleeding. Anemia is a very frequent systemic complication of inflammatory bowel disease and its diagnosis and treatment should not be neglected in patients with these diseases (Gisbert \& Gomollon, 2008). In the presented patient blood cell morphology and serum iron indices were carefully checked to exclude potential iron deficiency rather than its excess. Moreover, in the case of recurrent blood loss, no signs of iron overload should be expected. It appears that in this case the dysfunction of HFE protein due to the $\mathrm{C} 282 \mathrm{Y} / \mathrm{C} 282 \mathrm{Y}$ HFE gene mutation resulting in accumulation of iron protected against anemia. This factor caused advantageous modulation of the clinical course 


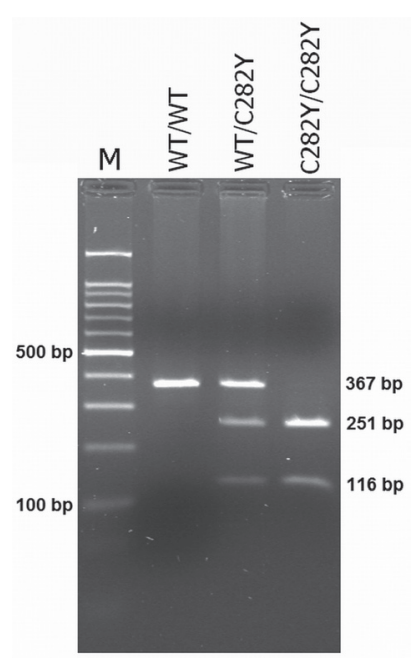

Figure 1. Determination of C282Y mutation of HFE gene by PCRRFLP analysis

M, 100 bp DNA ladder

of ulcerative colitis. The HLA region is implicated in pathogenesis of ulcerative colitis. Specific HLA-DR alleles are known to influence the phenotype of the disease (Hampe et al., 1999; Stokkers et al., 1999; Walters \& Silverberg; 2006). It could be speculated that HLA-DR alleles located on the short arm of chromosome 6 near the locus of the HFE gene may influence penetration of hereditary hemochromatosis type 1 . A stronger phenotypic expression of HFE gene mutations caused by the presence of specific HLA-DR genes would protect against anemia and become an advantageous modulator of UC clinical course (Ponsioen et al., 2001; Beutler et al., 2003). Additionally, in this patient and his younger brother mild unconjugated hyperbilirubinemia was diag-
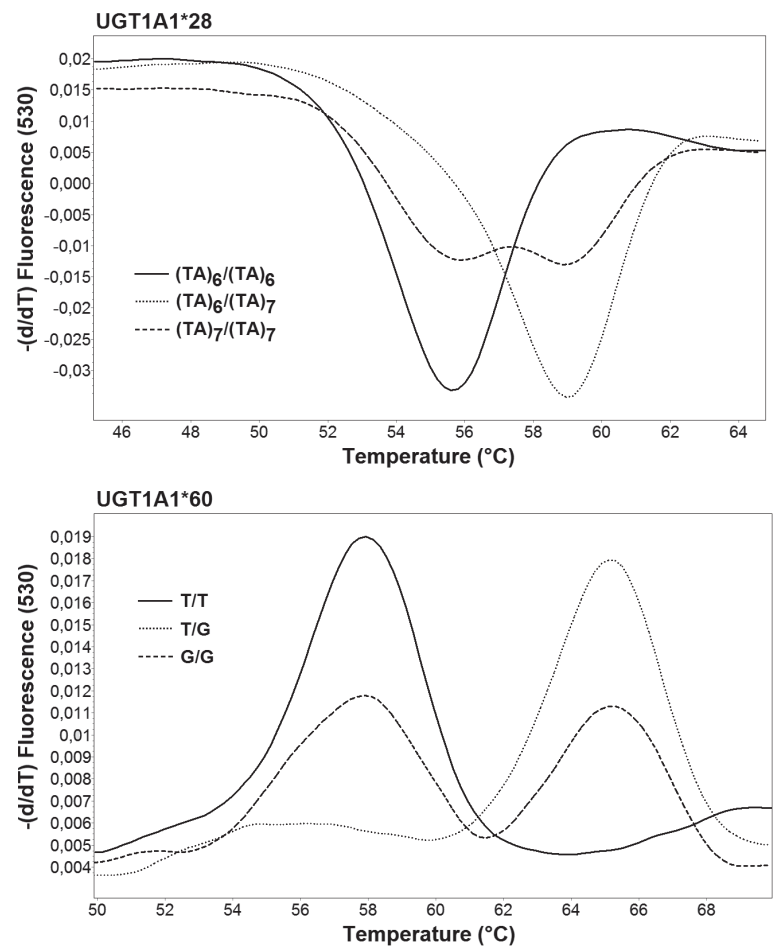

Figure 2. Genotyping of UGT1A1*28 (seven TA repeats in TATA box of UGT1A1 gene) and UGT1A1*60 (c.-3279T>G) polymorphisms performed by fluorescent molecular probes assays nosed. Based on molecular investigations the diagnosis of Gilbert syndrome was established. The recessive polymorphism A(TA) 7 TAA (UGT1A1*28) in which seven instead of six TA repeats are found in the TATA box of bilirubin uridine diphosphate glucuronyl transferase gene $(U G T 1 A 1)$ is responsible for most cases of Gilbert syndrome (Bosma et al., 1995). It often co-occurs with the homozygosity of the $T$ to $G$ substitution in the UGT1A1 gene start codon (c.-3279T $>$ G, also named UGT1A1*60) (Maruo et al., 2004). Although responsible for benign hyperbilirubinemia, this polymorphism may impair biotransformation of some drugs thus increasing the toxicity of xenobiotics requiring glucuronidation (Lankisch et al., 2006; Biason et al., 2008).

The effect of UGT1A1 gene polymorphism and mild hyperbilirubinemia on iron-overload-related disease is unknown. Location of the UGT1A1 gene on chromosome 2 excludes the concept of nearby genes affecting HFE-related hemochromatosis expression. There are several reports indicating strong antioxidant properties of bilirubin (McCarthy, 2007; Ollinger et al., 2007). Thus, elevated serum bilirubin might diminish oxidative stress and prevent organ damage caused by iron accumulation. Recently, Romanowski et al. (2009) proposed a different mechanism of bilirubin action on iron overload. Based on the observations of patients with $\mathrm{HH}$ and mutations of UGT1A1 gene they concluded that elevated levels of bilirubin might promote iron loading by decreasing oxidative stress and inhibiting hepcidin expression signalling due to lower inflammatory activity (Nicholas et al., 2002).

Unlike in chronic hepatitis $\mathrm{C}$, the presence of liver iron deposits and abnormalities of iron metabolism are not extensively studied in chronic hepatitis B. Mild or moderate iron overload not associated with HFE gene mutations probably is not very rare in patients infected with $\mathrm{HBV}$, but sufficient data from different populations is lacking. As in other chronic liver diseases, iron causes tissue injury through oxidative stress (Martinelli et al., 2004). Liver iron deposits that may accompany high necroinflammatory activity not only promote fibrogenesis resulting in accelerated progression to liver cirrhosis but also increase the risk of hepatocellular carcinogenesis. A synergistic, unfavourable effect of hereditary hemochromatosis and chronic viral hepatitis is therefore observed and urges application of appropriate, effective treatment. The course of $\mathrm{CHB}$ in the presented case was mild as it is often observed in HBV infection acquired in early childhood. Increased HBV replication and following intensification of necroinflammatory process due to immunosuppression or drug hepatotoxicity have been proposed to explain liver disease exacerbation observed during therapy of UC with azathioprine. This mechanism of liver damage was questionable in the presented patient because his serum activity of thiopurine methyltransferase was within the normal range - $9.36 \mathrm{nmol} /$ $\mathrm{ml} / \mathrm{h}$ (normal range $>5 \mathrm{nmol} / \mathrm{ml}$ per $\mathrm{h}$ ) (Gisbert et al., 2001).

Although exacerbation of liver disease observed in the presented case during azathioprine treatment could result in iron deposition in the liver, it should rather be found in macrophages as a result of necroinflammatory hepatocytic damage (Deugnier et al., 2008). However, iron deposits were detected in hepatocytes indicating primary character of iron loading as it is observed in HH. The patient is at present subjected to antiviral treatment with nucleoside analogues according to EASL recommendations (EASL, 2009). Interferon will not be administered because of high risk of exacerbation of ulcerative colitis. 
Phlebotomy is considered in the treatment of $\mathrm{HH}$ but now it is to be adjourned until antiviral therapy is effective and evaluation of iron metabolism parameters after inhibition of viral replication becomes possible.

The presented case illustrates problems in diagnostics related to the presence of numerous disease conditions in one patient. It should be taken into consideration that these diseases coexisting in one patient can mutually affect their symptoms creating specific diagnostic difficulties.

\section{REFERENCES}

Allen KJ, Gurrin LC, Constantine CC, Osborne NJ, Delatycki MB, Nicoll AJ, McLaren CE, Bahlo M, Nisselle AE, Vulpe CD, Anderson GJ, Southey MC, Giles GG, English DR, Hopper JL, Olynyk JK, Powell LW, Gertig DM (2008) Iron-overload-related disease in HFE hereditary hemochromatosis. N Engl J Med 358: 221-230.

Arnold J, Sangwaiya A, Bhatkal B, Geoghegan F, Busbridge M (2009) Hepcidin and inflammatory bowel disease: dual role in the host defense and iron homoeostasis. Eur J Gastroenterol Hepatol 21: 425-429.

Beutler E (2003) The HFE Cys282Tyr mutation as a necessary but not sufficient cause of clinical hereditary hemochromatosis. Blood 101: 3347-3350.

Beutler E, Felitti V, Gelbart T, Waalen J (2003) Haematological effects of the C282Y HFE mutation in homozygous and heterozygous states among subjects of northern and southern European ancestry. BrJ Haematol 120: 887-893.

Biason M, Masier S, Toffoli G (2008) UGT1A1*28 and other UGT1A1 polymorphisms as determinants of irinotecan toxicity. $J$ Chemother 20: 158-165.

Bomford A (2002) Genetics of haemochromatosis. Lancet 360: $1673-$ 1681.

Bosma PJ, Chowdhury JR, Bakker C, Gantla S, de Boer A, Oostra BA, Lindhout D, Tytgat GN, Jansen PL, Oude Elferink RP, Chowdhury NR (1995) The genetic basis of the reduced expression of bilirubin UDP-glucuronosyltransferase 1 in Gilbert's syndrome. N Engl J Med 333: $1171-1175$.

Bridle KR, Frazer DM, Wilkins SJ, Dixon JL, Purdie DM, Crawford DH, Subramanian VN, Powell LW, Anderson GJ, Ramm GA (2003) Disrupted hepcidin regulation in HFE-associated haemochromatosis and the liver as a regulator of body iron hemostasis. Lancet 361: 669-673.

Deugnier Y, Brissot P, Loréal O (2008) Iron and the liver: update 2008. J Hepatol 48 (Suppl 1): S113-S123.

EASL (2009) Clinical Practice Guidelines: Management of chronic hepatitis B. I Hepatol 50: 227-234.

Gisbert JP, Gomollon F (2008) Common misconceptions in the diagnosis and management of anemia in inflammatory bowel disease. Am J Gastroenterol 103: 1299-1307.

Gisbert JP, Gomollon F, Cura C, Luna M, Gonzalez-Lama Y, Pajares HM, Mate J, Guijarro LG (2001) Thiopurine methylotransferase activity in Spain: A study of 14,545 patients. Dig Dis Sci 52: 1262-1269.

Hampe J, Schreiber S, Shaw SH, Lau KF, Bridger S, Macpherson AJ, Cardon LR, Sakul H, Harris TJ, Buckler A, Hall J, Stokkers P, van Deventer SJ, Nürnberg P, Mirza MM, Lee JC, Lennard-Jones JE, Mathew CG, Curran ME (1999) A genomewide analysis provides evidence for novel linkages in inflammatory bowel disease in a large European cohort. Am J Hum Genet 64: 808-816.
Knight C, Murray KF (2009) Hepatobiliary associations with inflammatory bowel disease. Expert Rev Gastroenterol Hepatol 3: 681-691.

Kulaksiz H, Gehrke SG, Janetzko A, Rost D, Bruckner T, Kallinowski B, Stremmel W (2004) Pro-hepcidin: expression and cell specific localization in the liver and its regulation in hereditary haemochromatosis, chronic renal insufficiency, and renal anaemia. Gut 53: 735-743.

Lankisch TO, Moebius U, Wehmeier M, Behrens G, Manns MP, Schmidt RE, Strassburg CP (2006) Gilbert's disease and atazanavir: from phenotype to UDP-glucuronyltransferase haplotype. Hepatology 44: 1324-1332.

Martinelli AL, Filho AB, Franco RF, Tavella MH, Ramalho LN, Zucoloto S, Rodrigues SS, Zago MA (2004) Liver iron deposits in hepatitis B patients: association with severity of liver disease but not with hemochromatosis gene mutations. J Gastroenterol Hepatol 19: 1036-1041.

Maruo Y, D’Addario C, Mori A, Iwai M, Takahashi H, Sato H, Takeuchi Y (2004) Two linked polymorphic mutations (A(TA)7TAA and T-3279G) of UGT1A1 as the principal cause of Gilbert syndrome. Hum Genet 115: 525-526.

McCarty MF (2007) "Iatrogenic Gilbert syndrome" — A strategy for reducing vascular and cancer risk by increasing plasma unconjugated bilirubin Med Hypotheses 69: 974-994.

Nemeth E, Valore EV, Territo M, Schiller G, Lichtenstein S, Ganz T (2003) Hepcidin, a putative mediator of anemia of inflammation, is a type II acute phase-protein. Blood 101: 2461-2463.

Nicolas G, Chauvet C, Viatte L, Danan JL, Bigard X, Devaux I, Beaumont C, Kahn A, Vaulont S (2002) The gene encoding the iron regulatory peptide hepcidin is regulated by anemia hypoxia, and inflammation. J Clin Invest 110: 1037-1044.

Nicolas G, Bennoun M, Devaux C, Grandchamp B, Kahn A, Vaulont S (2003) Lack of hepcidin gene expression and severe tissue iron overload in upstream stimulatory factor 2 (USF2) knockout mice. Proc Natl Acad Sci USA 98: 8750-8755.

Ollinger R, Wang H, Yamashita K, Wegiel B, Thomas M, Margreiter R, Bach FH (2007) Therapeutic applications of bilirubin and biliverdin in transplantation. Antioxid Redox Signal 9: 1-11.

Pigeon C, Ilyin G, Courselaud B, Leroyer P, Turlin B, Brissot P, Loréal O (2001). A new mouse liver-specific gene, encoding a protein homologous to human antimicrobial peptide hepcidin, is overexpressed during iron overload. J Biol Chem 276: 7811-7819.

Ponsioen CY, Stokkers PC, vd Horst AR, Tytgat GN, van Deventer SJ (2001) A patient with hereditary hemochromatosis, ulcerative colitis, and primary sclerosing cholangitis: genetic aspects. Eur J Intern Med 12: $518-521$.

Ramasundara M, Leach ST, Lemberg DA, Day AS (2009) Defensins and inflammation: the role of defensins in inflammatory bowel disease. J Gastroenterol Hepatol 24: 202-208.

Romanowski T, Sikorska K, Bielawski KP (2009) UGT1A1 gene polymorphism as a potential factor inducing iron overload in the pathogenesis of type 1 hereditary hemochromatosis. Hepatol Res 39: 469-478.

Sikorska K, Stalke P, Jaskiewicz K, Romanowski T, Bielawski KP (2008) Could iron deposits in hepatocytes serve as a prognostic marker of HFE gene mutations? Hepatogastroenterology 55: 1024-1028.

Stokkers PC, Reitsma PH, Tytgat GN, van Deventer SJ (1999) HLADR and -DQ phenotypes in inflammatory bowel disease: a metaanalysis. Gut 45: 395-401.

Verga Falzacappa MV, Muckenthaler MU (2005) Hepcidin: iron-hormone and anti-microbial peptide. Gene 364: 37-44.

Walters TD, Silverberg MS (2006) Genetics of inflammatory bowel disease: current status and future directions. Can J Gastroenterol. 20: 633-639. 